\title{
Historia Ecclesiae Evangelicae [...] tredecim oppidis Scepusii (1830)
}

Munyay Antal Lajos munkája a szepesi evangélikusok történetéről

„Christianus persecutionem patiens"

(Andreas Günther, 1675)

A „mártirológia” igen széles körű jelenség, noha a kifejezést leginkább az egyházak keretében használják. Ha csak a kora újkori Európát idézzük fel, nemcsak az ókori keresztény vértanúk, a meggyilkolt hittérítők kultusza jelenik meg, hanem mind a katolikus, mind a protestáns mártírokat is előtérbe állítják. Husz János, Szervét Mihály, a Cromwell Angliájában üldözött katolikus papok, vagy a Pombal márki portugáliai börtönébe került, Dél-Amerikában térítő, Magyarországról származó jezsuiták és sokan mások tartoznak e sorba. Ám Galilei, Puskin vagy éppen Táncsics Mihály és Semmelweis életírói is hasonló modelleket követtek. Nálunk a „protestáns gályarab lelkészek” élettörténete már a kortársaktól kezdve mindmáig ilyen „írásmódot” (discours) használt.

Minthogy jelen kötet igen sokféle témát dolgozott fel, további ilyen mártirológiai távlatokra nem is kell most utalnom.

$\mathrm{Az}$ „egyházi” mártirológia kora újkori protestáns változatainak esetében csak két fontos és sajátos körülményt említenek. Az egyik az a „történetkeret”, amelyet a mártíromság ideológiája képvisel: gyakrabban lelkészek, kiválasztott személyek - ritkábban egyszerűbb emberek - életében a „hitben való állhatatosság” a legfontosabb erény. Nem az egyházépítés, a bibliafordítás vagy a gyógyító képesség az erős hit bizonysága, hanem a szenvedés, üldöztetés, gyakran az erőszakos halál. Hogy milyen széles távlatokban érzékelhető a különböző értékeket kifejező jeles személyek kultusza, könnyen beláthatjuk. Az egészen extrém életvitelt követő remeték esetében a világtól való elfordulás, olykor a „tétlenség” az erény - és nemcsak a keresztények között. A buddhista vallás is ismeri a "tanvédo"” (szanszkrit dharmapāla) fogalmát. Ott istenségeket, démonokat illetnek e szóval. Sőt, például a kelet-tibeti „népi” buddhizmus-lámaizmusban, a hegyeket vagy azok „,szellemeit” is „tanvédö"-nek nevezik (chos skyong).

Az európai egyháztörténetben viszont valóságos ember az, aki rendszerezi, tisztázza, pontosan értelmezi a vallás ismert mozzanatait. Egész sor kiváló teológus, pap vagy tudós, például Aquinói Szent Tamás, Szent Bonaventura, Nagy Szent Albert (Albertus Magnus), Raimundus Lullus, William Ockham, Canterburyi Szent Anzelm, Roger Bacon, Petrus Lombardus és mások kaptak erre utaló állandó mellékneveket, például doctor angelicus, autenticus, devotus, ecstaticus, famosissimus, fundatissimus, ingeniosus, invicibilis, reverendus, scholasticus, seraficus, subtilis, 
universalis, venerabilis stb. Egy-egy kiválóság olykor több ilyen jelzőt is megkapott, illetve ugyanazt a jelzőt többen is viselhették. Ezek a tanítás, emelkedettség - és nem a szenvedés vagy mártíromság erényére utalnak. Csak első tekintetre meglepő, hogy nem csupán a középkori kereszténység vagy a későbbi katolicizmus, hanem az újkori protestantizmus is milyen széles körben használja e modelleket: a vértanúktól a csendben építkezőkig. Az emberevők világában, vagy a háborúkban megölt miszszionáriusoktól Albert Schweitzerig vagy Martin Niemöllertől Kalkuttai Teréz Anyáig igazán sokféle személyt idealizál a köztudat - és az egyházak is. (Ám igazában akkor csodálkozhatnánk, ha ez nem így volna. Hiszen például az új vallási mozgalmak az orosz Avvakum protopópától és a bahái-alapítóinak egymást öldöklő nemzedékeitől egészen a marihuana-fogyasztó reggae-énekes, Bob Marley „raszta-fári” kultuszáig ugyanilyen „mártír”-életrajzot fogalmaztak meg.)

További sajátossága a protestáns mártirológiának a csodák és szentek kritikája, a szupranormális és fabulózus elemek elvetése, ugyanakkor a mindennapi élet és az (egyház)történelmi események előtérbe helyezése. Mind a kortársi, mind a későbbi szövegek a vallási vezetők és a tömegek életében a valódi eseményeket helyezik előtérbe. Ha gyakori is - például az „ébredések” beszámolóiban - a hatalmas hatású prédikációk leírása, amelyek eredményeként százak vagy ezrek válnak hívőkké - azért, például, Tessedik Sámuel saját életírásai, meg mások rá vonatkozó szövegei eléggé földhözragadtak: ellenségeivel való küzdelmei az agrotechnika, a gyümölcsfák kivágása, a liturgia reformja vagy egy utópisztikusan racionális falutervezés körül forognak - nagyon is valóságos ellenfelekkel szemben.

Mindennek következtében bizonyos magyarországi protestáns egyháztörténeti források nem is a „vértanư", inkább a „jó pásztor” ideáltípusát helyezik előtérbe, még extrém esetben is, mint a szabadságharcban részt vevő (és 1849 júniusában kivégzett) pozsonyi evangélikus lelkész, Rázga Pál, vagy a református püspök, Ravasz László, akit egyik utódja „inkább okos volt, mint erős” szavakkal dicsért.

Különösen ez utóbbi körülmény (a mindennnapi élet elötérbe állítása) miatt az egyes tájak vagy korok egyháztörténetei sokban különbözhetnek egymástól. Egyesek a szinte irracionális erők következetes műveként szüntelenül ostromolt protestáns lelki várakról szólnak - más szövegekben még a sérelmeket is szinte objektív módon kezelik. Az ilyen ténybeli és feldolgozásbeli különbségeket jól érzékelhetjük a ránk maradt forrásokban, amelyek egymástól igazán eltérő módon mutatnak be fontos szereplőket. Jó példa erre a világiaknak az egyházvezetésben való részvételét oly szigorral hirdető debreceni református püspök, Sinai Miklós változatos értékelése.

Ám ehhez rögtön hozzá tehetjük, hogy igen sok ilyen egyháztörténeti forrásmü leginkább a különös változatok - eddig nem talált méltó feldolgozóra. Az alábbiakban egy ilyen könyvre kívánom felhívni a figyelmet. 
Köztudott, hogy a magyarországi evangélikus egyház története nyelvileg, etnikailag, területileg több nagy csoportra tagolható. A Felvidéken német és szlovák gyülekezetek mellett éltek a magyarok. És a hasonló hazai egyházszervezet, meg a hasonló külföldi kapcsolatok ellenére is jócskán eltért mondjuk Sopron és vidéke, a Kemenesalja vagy az erdélyi Királyföld evangélikusainak élete.

A bemutatandó munka szepességi evangélikusokkal foglalkozik, és itt még sajátosabbak voltak a történelmi körülmények.

Köztudott, hogy Luxemburgi Zsigmond 1412-ben 13 szepesi várost elzálogosított sógorának, II. Ulászló lengyel királynak. Ez még jóval a reformáció előtt történt. A Tátra alatti tájnak mind a magyar, mind a lengyel részén egymással összefüggő események során terjedt el a protestantizmus, gyakorlatilag az ágostai ágazat. A városokat csak 1773-ban váltotta vissza Mária Terézia. Minthogy 13-nál több, összesen 24 szepesi város volt, a lengyel zálogba pedig más három (nem-szepesi) város is került, a mindennapi élet e három és fél évszázad (azaz legalább tíz generáció) alatt akár az egyes településeket tekintve is bonyolult volt. A városok lakossága eredetileg elsősorban német nyelvü és kultúrájú volt, ám hovatovább a szlovákok és magyarok mellett lengyelek is megjelentek. Az elzálogosított területeken lengyel közigazgatás és jogszolgáltatás volt, a lengyel koronát egy kormányzó képviselte. Lengyel gyalogosok csapata őrizte a területet. Mind a katolikus, mind a protestáns egyházszervezeti beosztás többször is módosult e tájon. A műveltségi és teológiai áramlatok gyakorlatilag mindig átjutottak a határokon. A viszonylag fejlett kézműipar, még inkább a kereskedelem, aránylag gazdag tájjá tette a Szepességet: nevezetes iskolái, nyomdái huzamosan müködtek. Noha a háborúk, felkelések e tájat sem kímélték meg teljesen, az akkori alföldi, ám akár az erdélyi területekhez képest kiszámítható, sőt békés volt itt az élet.

Protestáns (és katolikus) egyháztörténetünk és művelődéstörténetünk sokszor foglalkozott e sajátos vidékkel. Ám modern, áttekintő egyháztörténeti munka eddig nem készült erről. A szepesi városok már a középkorban igen szoros kapcsolatban álltak a felvidéki királyi bányavárosokkal, és maguk egy fraternitasba tömörültek, amely rendszer a reformáció után is fennmaradt. A reformáció első nagy, gyors és eredményes hulláma után a Szepesi Prépost volt a Szepesség nyugati részén megmaradt katolikusok vezetője. Itt, a gyakran erőszakos ellenreformáció eredményeként, végül 1674-ben a protestáns templomokat elvették, lelkészeiket elüzték. A lengyel zálogban levő városokban viszont kivétel nélkül, mindenütt megmaradtak az evangélikus gyülekezetek. Ugyanakkor a mindennapi vallásgyakorlatot (például a Mária-kultuszt) tekintve is igen erős volt a katolikus hatás. A 18. század végén Magyarországhoz visszakerült (akkor még jellemzően németajkú) szepesi városok is protestánsok maradtak, ám - a türelmi rendelet ellenére is - a Szepesség nyugati részén igen csekély volt az ismét protestánssá lett gyülekezetek befolyása. A 18. század végén újra átalakították és egyesítették az evangélikus egyházkerületeket. Ekkor föként a „tiszai”, egyre inkább magyar nyelvű vidékkel való kapcsolatok domináltak.

Erről az érdekes egyháztörténetről máig azt a munkát szokás forrásként említe- 
ni, amelyről az alábbiakban próbálok képet adni. Mégsem sokan láthatták e könyvet. Nyilván ennek az is oka, hogy a könyv nem Magyarországon jelent meg, ráadásul latin nyelvü.

1830-ban Halberstadtban, Carolus Brüggeman nyomdájában adták ki a Historia Ecclesiae Evangelicae Augustanae Confessioni addictorum in Hungaria universe; precipue vero in Tredecim Oppidis Scepusii címü könyvet. ${ }^{1}$

A Praefatio vázolja a munka célját, megemlíti, főként milyen külföldi vagy hazai írásos forrásokra támaszkodott a szerző. Ezek a magyarországi egyházak történetére, föként a protestánsok elleni támadásokra térnek ki, itt sok, ma alig ismert dokumentumot említve. Ugyanitt részletes tárgymutató (index rerum) is olvasható. A könyv „általános” része (pars generalis) a kezdetektől a maga koráig tárgyalja a magyarországi evangélikus egyház történetét és szervezetét, másutt szintén nem említett források bevonásával. (Âm ebben Erdély nem szerepel.) A közvetlen adatbemutató rész (pars specialis, a 125-229. lapokon) a tizenhárom szepesi város evangélikus egyházának történetét mutatja be, öt szakaszra osztva. Már ez is adatokban gazdag forrásmunka, majd ez után (a 230-304. lapokon) különböző dokumentumokat közöl a könyv. A kötet végén sajtóhiba-javitások találhatók.

Mind az általános, mind a részletes fejezet érdemes az olvasásra. Nem nagyszabású emlékirat, nem is vitairat, hanem adattár, amely főként az egyházszervezetet és annak határozatait mutatja be. Folyékony latinsága is tárgyszerü, gondolom, pontosan tükrözi a maga korának szóhasználatát. Irodalmi vagy teológiai babérokra azonban nem törekszik.

A szerző neve nincs feltüntetve, amit nem tudok egyértelmüen a kor protestánsellenességével összekapcsolni, mivel maga a könyv igen sok személyt név szerint említ. Tudjuk azonban, hogy Munyay Antal Lajos² műve. A természetesen evangélikus Munyay lelkészi család sarja. Eperjesen, Lőcsén, majd Pozsonyban (a nevezetes evangélikus líceumban) tanul. A Felvidéken és külföldön nevelösködik. 1811-ben iratkozik be a wittenbergi egyetemre. Már egy év után hazatér, ismét nevelősködik. Ezt nyilván anyagi helyzete indokolta. 1815-ben választják Szepesolaszi (Wallendorf) lelkészének. 1832-től teológiai tanár Eperjesen, a többször a katolikusok által elvett, majd visszaszerzett, végül 1785-ben visszavásárolt kollégiumban. Az akkori tiszai egyházkerületben hosszabb ideig volt föjegyző. Nyilván emiatt is sok dokumentumhoz juthatott hozzá. Egyháztörténeti ismeretei alapján őt szemelték ki ünnepi szónoknak 1830-ban az Ágostai Hitvallás háromszáz éves jubileumán, valamint 1835-ben az eperjesi (ismét evangélikus) kollégium ötvenéves évfordulóján rendezett ünnepélyeken. Szepesolaszi egyházának jeles alkalmait német nyelvű írásokban méltatta. Egy másik irata a kisszebeni szlovák evangélikus templom felavatására (1820) készült. Két lelkésztársával együtt két-

\footnotetext{
${ }^{1}$ Terjedelme: XVI, $304+[4]$.

${ }^{2}$ 1787. október 26-án született Kapinémetfaluban (ma: Nemcovce), amely a 19. századra már kis szlovák falu Eperjes és Bártfa között. 1849. december 2-án halt meg Eperjesen.
} 
kötetes német nyelvű prédikációgyüjteményt jelentetett meg. Szinte élete végéig készített gyászbeszédeket, fordításokat. Négy latin nyelvü művét ismerjük. Ezek közül az első a most tárgyalt munka. A teológiai, bölcseleti és jogi oktatást szolgálja beszéde: Oratio, qua classis theologiae-philosophiae-juridicae cives [...] ad rectum epuli sacri usum [...] praeparabat (Eperjes, 1832). Egyházjogi áttekintés: Synopsis iurium et gravaminum ecclesiae evangelicae in Hungaria (Eperjes, 1832). Az eperjesi kollégium történetét mutatja be: Fortuna secunda et altera (Eperjes, 1835). A nyilván háromnyelvü (ezen kívül latinul is jól tudó) lelkész munkája mindig közvetlen, gyakorlati célokat szolgált. Munkáit a kortársi és későbbi egyházi áttekintések, a magyar bibliográfák rendre felsorolják.

Munyay Historia Ecclesiae Evangelicae címü könyve nem alkalmi kiadvány, nem is a sérelmek jegyzéke. Bizonyos fokig nyilván a nemzetközi közvélemény tájékoztatására készült, ám részleteiben az itthoni múltat és az abban szereplőket mutatja be, mintegy adattárként a kortársak és az utókor számára. Arra törekszik, hogy a 13 szepesi város evangélikus egyházának fontos történeti dokumentumait sorolja fel. Noha a szerző mindennapi életében a sajátos helyi hagyományokat követte, művében nem elmélkedik arról, miként is volt jobb a sorsa az ottani evangélikusoknak a buzgó katolikus és ellenreformációs lengyel világban - mint Magyarországon. Nem részletezi az általa említett egyének nyelvi vagy kulturális hovatartozását. Természetesnek veszi a több nyelv és etnikum egymás mellett meglétét. A maga esetében sem merül fel a hovatartozás kérdése. A teológiai irányzatokra is kevés figyelmet fordít. Ám a mégannyira praktikus munka olyan korról és területről számol be, ahol a vallások konfliktusai gyakran a mártíromságig vezettek.

Minthogy a tények érdekelték a szerzőt, nem könnyü azt az ideológiát megtalálni, amelyből kiindult. A bevezetésben is csupán forrásainak adatait említi, nem tárgyalja, ezek milyen felfogásban mutatják be az evangélikus egyházat.

A könyv általános részében Munyay a Szepességen „kívüli” evangélikus területet mutatja be, felsorolja a protestánssá lett családokat, a nyomdák megjelenését, a különböző gyüléseken (synodus, conventus) elfogadott „hitvallásokat”. Jellemzi a Habsburg-uralkodókat, és az ellenreformáció vezetőit, így például Pázmányt. Akit különben „turpis Apostata” jelzővel illet, és arra utal, hogy Pázmány ifúkori vallásváltoztatásának mintegy kompenzációjaként volt oly engesztelhetetlen ellensége a protestánsoknak. Amikor a gályarabsághoz vezető pozsonyi rendkívüli törvényszék (1675) eseményeit említi, itt is a tények és nevek felsorolását adja. A történeti áttekintés megfelelő részeiben utal a felkelésekre, szabadságharcokra is - ismét röviden. Ahogy közeledik a maga koráig, és például Mária Terézia működését írja le, csak felsorolja a templomok és iskolák elvételét és ezek hányatott történetét. Úgy fogalmaz, hogy az adatok mintegy magukért beszéljenek. II. József korából elsősorban a türelmi rendeletet mutatja be, II. Lipót és I. Ferenc törvénykezéséről is pontosan referál. Életrajzának ismeretében érthető, hogy az evangélikus felsőoktatás (collegium) kérdései külön helyet kapnak.

A fejezet végén általában is jellemzi a magyarországi evangélikus egyházat, ab- 
ban a tekintetben, hogyan határolja el magát az államegyháztól és az „eretnekek”től (haeretici). Ezt a részt az evangélikus szuperintendensek magyarázatokkal ellátott jegyzéke követi.

A könyv második fele foglalkozik közvetlenül a Szepességgel. A közismert történeti tényeket röviden jelzi. Mint említettük, a reformáció kezdetétől 1825-ig terjedő időszakot négy „periódus”-ra bontja. Minthogy itt egy kisebb, jól körülhatárolható területről beszél, a bemutatás közelibb, az egyes eseményeket, helyszíneket, szereplőket érzékletesebben írja le, noha itt sem jellemzi és ritkán minősíti. Különösen az 1772 előtti részekben természetesen a sajátos lengyel viszonyokra és ezek szereplőire is kitér. A magyar államba visszatérés eseményeit a „harmadik periódus” fejezetében írja le. A rövid negyedik fejezet jut el 1825-ig. Az iskolákat, ennek intézményeit, a parókusokat, az egyházkerület írásban megmaradt döntéseit és tisztségviselőit is lehető teljességgel adatolja. Az ún. szepességi hitvallás szövege (ezt először 1549-ben fogalmazták meg, és végül is 1587-ben fogadta el a szepességi városok gyülése), valamint Pázmány 1632-es kiközösítő iratának teljes szövege a függelékben olvasható.

Feltűnő, hogy a protestánsüldözések eseményeit említve sem használja a „mártír" szót, egyáltalán az ilyen értelmezést. A leginkább nyilvánvaló ez az 1670-es évek leírásakor. Amint tudjuk, már az évtized elején Magyarországon egyre gyakoribb a protestáns templomok, iskolák elvétele, a lelkészek és tanárok elüldözése, nagy öszszegü pénzbírságok követelése. A szepességi városok próbálnak ellenállni, és a lengyel kormányzóhoz, Stanislaw Lubomirski herceghez, illetve a lengyel katonákat vezető kapitányokhoz fordulni - kevés sikerrel. A pozsonyi rendkívüli törvényszék elé mégsem mennek el a protestáns lelkészek - más államhoz tartozásukra hivatkozva. Ám Bársony György szepesi katolikus prépost külön összehívja Szepesváraljára a Iudicium Varaliensis törvényszékét, amely a szokásos vádakat (köztük a felségárulást és titkos szervezkedést is) hozza fel az evangélikusok ellen, ezért a templomok, iskolák és nyomdák átadását, valamint a lelkészek elüzését követeli (hacsak át nem térnek katolikussá). A protestánsok minden ellenállása ellenére is - legfeljebb némi késéssel - mindezt el is kezdik foganatosítani. Csak az új lengyel király, Sobieski János trónra lépte után, 1682-ben enyhül a szigor, és kezdik eltürni a nem-nyilvános (tehát a bezárt magánházakban történő) protestáns egyházi életet. Mégis csupán a 18. század elejére szünik meg a protestánsüldözés teljes szigora.

Munyay nem hallgatja el a tényeket - csak éppen nem említi a mártírság fogalmát. Ez az adattárként is fontos müvének talán legérdekesebb tanulsága.

E hallgatás okát nem tudom könnyen megadni. Az 1820-as években sem volt teljes nálunk a vallási (és állami) tolerancia, a Szepességben sem. A külföldi (elsősorban a német) protestánsok nyilván tudtak a korábbi protestánsüldözésekről. Noha ekkorra már elmúlt a nyílt vallásháborúk kora, azért erre mindkét részről visszautaltak, a maguk hőseit és mártírjait is említették.

A „gyászévtized” megítélése már a kortársak között sem volt egyértelmű. Jól mutatja ezt a Szepességből 1671-ben elüzött Andreas Günther több műve, amelyek közül 
1675-ös stralsundi prédikációja ([...] Gründlicher Bericht, wie und warum Christus aus Ungerland weiche) váltott ki nagyobb visszhangot, amelyre vitairat, majd erre válaszok is születtek. A vita középpontjában éppen az állt: indokolt volt-e a lelkészek elmenekülése a Szepességből? Az ugyancsak a Szepességből 1674-ben német földre menekült Christoph Klesch már 1679-ben kiadta Succinta papisticae in 13 Scepusiacis Hungariae oppidis anno [...] 1674. institutae deformationis enarratio címü beszámolóját. Ebben szerepelnek az Isten büntetése és a mártíromság toposzok, a katolikusok megbélyegzése. Munyay e müveket nem említi, ám ez nem jelenti azt, hogy nem is láthatta ezeket.

Azt, hogy nem véletlen Munyay „szenvtelen” fogalmazása, éppen a legutóbb említett művekkel összevetve vélhetjük. A „gyászévtized” idején a szepességi lelkészek közül többen is német földre menekültek. Természetes módon, hiszen anyanyelvük német volt, német egyetemeken tanultak. És ekkor ott - akarva-akaratlanul is - a hit mártírjaiként jelentek meg. Személyes beszámolóik ilyen igénynek megfelelő módon voltak megfogalmazva, illetve a közönség mindenképpen így értelmezte ezeket.

Egyébként a Magyarországra hasonló úton érkezett külföldiek is könnyen kerülhettek ugyanilyen paradigmába. Gondoljunk csak Giorgio Blandrata, Johannes Amos Comenius vagy Isaac Basire alakjára, hogy 19. vagy 20. századi példákat ne is említsünk.

Egy másik (ideológiai) párhuzam-ellentét is megfigyelhető. A kötet végén közölték Pázmány 1632. december végén nyilvánosan felolvasandó „Kiátkozó formuláját" (Formula excommunicationis Pastorum Viginti Quatuor Regalium in Scepusio, auctoritate Petri Pázmanni Archi-Espiscopi Strigoniensis). Ez a szenvedélyes és kiváló retorikával megfogalmazott írás nemcsak a protestánsok által felsőbbségnek el nem ismert esztergomi katolikus érsek nevében szól, hanem igen tudatosan kiemeli a protestánsokétól eltérő mozzanatokat (Szűz Mária, a szentek, angyalok, apostolok tiszteletét). A bevezetés határozottan dokumentálja, kinek a nevében zajlik a kiközösítés: „Ex auctoritate Dei Omnipotentis Patris et Filii et Spiritus Sancti et Sanctae Mariae Virginis, matris Domini nostri Jesu Christi, et sanctorum Angelorum et Archangelorum et St. Michaëlis et St. Baptistae, et ex vice B. Petri Apostoli et aliorum Apostolorum, et S. Stephani et omnium Martyrum, Sylvestri et D. Adalberti et omnium Confessorum, et S. Adelgundis, et S. Virginum et Omnium Sanctorum [...]"

Vagyis itt a mártírok és hitvallók éppen a „másik” oldalon állnak, „nem-protestáns" fogalmakként. Nem a kiközösítettek, hanem a kiközösítők oldalán említik a mártírokat. Övelük a protestáns lelkészek, ha éreztek is szolidaritást - ezt nem fejezték ki.

Munyay könyve mind általában véve, mind a Szepességet illetően - szinte a szerző akaratán kívül - így nyer különös értelmet, mint a „mártír”-toposzon kívül maradó munka. Ez a „nem-heroizáló”, csak a tényeket objektív módon regisztráló megoldás annál inkább lehetséges volt, mivel a felvidéki protestánsok hosszú időn át tartó üldöztetésének és szenvedéseinek története ekkor országszerte ismert ténnyé vált. 
Egyébként 1830-ban német földön már kevesen ismerhették az elzálogosított, majd visszavásárolt területet, és azt a tényt, hogy az itteni evangélikusokra évszázadokon át mind a magyar, mind a lengyel katolikus egyház milyen különös figyelmet fordított. Mivel az akkori magyar Felvidéken igen sok helyen voltak német evangélikusok (Pozsonyban, a bányavárosokban, stb.), ezek különbségeit a külföld aligha érzékelte. Ezért viszont informatív értéke volt e könyvnek, és ekkor még tekintélyes volt az a közönség, amely tudott olvasni latinul. Arra viszont nincs adatom, hogy Munyay könyve külföldön csakugyan „hatott”-e?

\section{VILmos Voigt}

Historia Ecclesiae Evangelicae [...] tredecim oppidis Scepusii (1830) Antal Lajos Munyay's Book on the History of the Lutherans of the County of Szepes (comitatus Scepusiensi)

This study analyses a book which was published in 1830 in Halberstadt (Kingdom of Prussia) by Carolus Brüggeman: Historia Ecclesiae Evangelicae Augustanae Confessioni addictorum in Hungaria universe; precipue vero in Tredecim Oppidis Scepusii. The author, Antal Lajos Munyay, a Lutheran preacher whose name did not appear in the book, interpreted the history of the Lutherans of the county of Szepes (comitatus Scepusiensi) from the Reformation to the nineteenth century. Munyay did not mention the word "martyr" even in the context of the Protestan persecutions of the 1670s. The present study thus tries to disclose the reasons for this surprisingly neutral narrative of early modern Lutheran history in Upper Hungary.

\footnotetext{
${ }^{3}$ Megjegyzés a szakirodalomról. A dolgozatomban említett művek adatait a föszövegben megadtam. Az általában használt bibliográfiák és lexikonok megfelelő cikkei jók, de nem teljesek, és régiek is. (SZINNYEI József, Magyar írók élete és munkái, Bp., Hornyánszky, 1891-1914; ZováNYi Jenő, Magyarországi protestáns egyháztörténeti lexikon, kiad. LADÁNYi Sándor, Bp., MRE Zsinati Iroda Sajtóosztálya, 1977 stb.) Nem volt célom a Szepességre általában vonatkozó gazdag szakirodalom felsorolása, mivel e vidék történetét csak igen vázlatosan foglalhattam össze. A szlovákiai egyháztörténetek közül számunkra a legérdekesebb a kiváló evangélikus egyháztörténész közismert műve - Ján KvačAlA, Dejiny reformácie na Slovensku. 1517-1711, Liptovský Sv. Mikulaš, Tranoscius, 1935. Ez azonban nem tárgyalja a későbbi évszázadokat. Az új áttekintések közül a leginkább használható: Daniel VeselÝ, Dejiny krestanstva a reformácie na Slovensku, Bratislava, EBF, 1998. Ezek azonban külön nem tárgyalják a szepesi evangélikusok sajátos történetét. A budapesti Szent Pál Akadémián (Kulcsár Árpád vezetésével) 2007-ben készült el Peter MinÁrik Reformácia na Spiši címü disszertációja. Ennek I. és II. része megjelent a Logos 4(2008) és 5(2009) számaiban. Ez pontos munka, településenként halad, helytörténeti és egyéb adatok felhasználásával. Azonban - meglepetésemre - Munyay munkáját nem ismeri. Eggyel több érv, hogy érdemes volt most felhívni a figyelmet rá.
} 